\title{
PRELIMINARY ESTIMATION ON AIR POLLUTION LOAD OVER BOGOR CITY TOWARDS DEVELOPMENT OF CLEAN AIR ACTION PLAN
}

\section{STUDI AWAL PERHITUNGAN BEBAN EMISI KOTA BOGOR SEBAGAI DASAR PENYUSUNAN RENCANA AKSI UDARA BERSIH}

\author{
Didin Agustian Permadi ${ }^{1}$, Mila Dirgawati ${ }^{1}$, Agung Ghani ${ }^{1}$, and Widi Hermawan ${ }^{1}$ \\ ${ }^{1}$ Institut Teknologi Nasional Bandung, Environmental Engineering, PHH Mustapha No 23, \\ Bandung, Indonesia, 40124, e-mail: email: didin@itenas.ac.id
}

Diterima tanggal 14 April 2020, disetujui tanggal 27 April 2020

\begin{abstract}
Emission inventory (EI) data are crucial to provide source apportionment and relative strength of various air pollutant sources in a city. The process of EI compilation can be either bottom-up or top-down, which depends on data availability and other resources. For a city like Bogor, known as a buffer zone of the capital of the Republic of Indonesia, these EI data are now available only for greenhouse gases (GHGs) but not for the air pollutants. Therefore, a top-down EI was designed and implemented for the city in the base year of 2016. Note that the sources of activity data were compiled from the previously arranged GHGs EI database as well as some other data gathered from the local authority. We adopted the EI framework of the Atmospheric Brown Cloud Emission Inventory Manual spreadsheet for the compilation. We included $\mathrm{SO}_{2}, \mathrm{CO}, \mathrm{NO}_{2}, \mathrm{PM}_{10}, \mathrm{PM}_{2.5}, \mathrm{NMVOC}$, and PM components (black carbon and organic carbon). Point sources, area sources, as well as mobile sources, were considered in the emission estimation. The latter species were included as they are known as strong short-lived climate-forcing pollutants (SLCPs). On-road transport contributed significantly to $\mathrm{SO}_{2}, \mathrm{NMVOC}$, and $\mathrm{PM}_{2.5}$, with a portion of 60 $86 \%$ of the total emission. Industrial combustion sources dominated the shares to the total emissions of $\mathrm{NO}_{x}(91 \%)$ and $\mathrm{CO}(92 \%)$. Based on this baseline information, we then proposed the source wise clean air action plan for the city in order to reduce the emission. A more accurate and up to date EI database should be done through a survey to get local representative activity data and to be compiled on a regular basis.
\end{abstract}

Keywords: Emission inventory, emission sources, air pollutants, clean air action plan, on-road transport, industry.

\begin{abstract}
ABSTRAK
Inventarisasi emisi (IE) adalah informasi penting yang dibutuhkan untuk mendapatkan data kontribusi dari berbagai sumber emisi terhadap total emisi pencemar udara di suatu kota. Proses kompilasi IE bisa secara bottom-up atau top-down tergantung dari ketersediaan data dan juga sumber daya. Untuk Kota Bogor, yang dikenal sebagai daerah penyangga ibu kota, data IE hanya tersedia untuk Gas Rumah Kaca (GRK), adapun untuk pencemar udara belum pernah dilakukan. Oleh karena itu, penelitian ini dilakukan untuk menginisiasi IE untuk Kota Bogor yang mencakup pencemar udara untuk tahun dasar 2016. Sumber data aktifitas dari berbagai sumber pencemar diambil dari laporan IE GRK untuk Kota Bogor ditambah dengan data tambahan yang diperoleh dari instansi setempat. Metodologi IE ini mengacu kepada buku manual "Atmospheric Brown Cloud Emission Inventory Manual". Parameter-parameter pencemar udara yang dimasukkan adalah $\mathrm{SO}_{2}, \mathrm{CO}, \mathrm{NO}, \mathrm{NMVOC}$, partikulat dan komponennya seperti black carbon (BC) dan organic carbon (OC). Sumber-sumber yang ditinjau untuk perhitungan beban emisi adalah sumber titik, sumber area, dan juga sumber bergerak. Beberapa pencemar seperti BC dan OC termasuk dalam short-lived climate-forcing pollutants (SLCPS)yang berpengaruh terhadap perubahan iklim. Sumber bergerak (kendaraan bermotor) berkontribusi signifikan terhadap total emisi $\mathrm{SO}_{2}$, NMVOC, and $P M_{2.5}$ dengan rentang kontribusi sebesar $60-86 \%$. Industri berkontribusi dominan terhadap total emisi $N O_{x}(91 \%)$ dan CO (92\%). Informasi dasar beban emisi untuk tahun 2016 ini kemudian dapat menjadi dasar untuk penentuan prioritas program penurunan emisi yang disusun dalam dokumen Rencana Aksi Udara Bersih untuk Kota Bogor. Penelitian lanjutan perlu dilakukan untuk melibatkan data survey untuk pendekatan kompilasi IE secara bottom-up dan perlu diperbaharui secara reguler.
\end{abstract}

Kata kunci: Inventarisasi emisi, sumber emisi, pencemar udara, rencana aksi udara bersih, sumber bergerak, industri. 


\section{INTRODUCTION}

Air pollution can aggravate the condition of patients with acute respiratory infections (ARI). It can even cause death, especially to those who exposed to high concentrations of PM2.5, while other air pollutants could also contribute to other health effects. Existing studies in several urban areas in Asia showed a strong correlation between the number of ARI patients and particulate air quality [1] [2].

There has been growing efforts worldwide on the development of Clean Air Action Plan (CAAP) for city level to harmonize plan on emission reduction strategy [3].

As an example, 5-year CAAP implemented in 2013 was reported to successfully reduce air pollutant emissions and improve ambient air quality in Beijing, China [4]. The key success of the program was sufficient information on the air quality management technical tools, including emission inventory (EI) data. In line with the currently growing global initiatives, there is a need to prepare CAAP for the city of Bogor, the buffer zone of the capital city of Indonesia. The main aim is to identify actions that can reduce emissions from major pollutant sources in a cost-effective manner and improve the air quality management system. For this reason, it is necessary to have a clear picture of the sources and characteristics of air pollutants in the city of Bogor, in terms of the emission load. Also, the contribution of each source to the total emission load by recording pollutant sources and the number of emissions in a particular area and a certain period [5].

This EI activity is the first step along with monitoring ambient air quality in an air quality management (AQM) effort in urban areas. The results of the EI can serve as the basis for determining the strategies and action plans of AQM in an area. The Ministry of Environment and Forestry also stated that the strategy to reduce air pollutant emissions was prepared based on the priority of air pollutants to be handled, the number of pollutants to be reduced, and the sources of air pollutants that contributed significantly to air pollution in a city [5].

In Indonesia, air pollutant EI was previously done either for city or national levels [6][7]. Few other studies were reported for other cities in Indonesia, but still fragmented, either fewer sources were covered or the base year was too obsoleted.

To our best knowledge, the only previous EI work was carried out for Jakarta Metropolitan Area (JMA) (i.e. Bogor, Tangerang, Depok, Bekasi) for the base year of 1996. Still, data were not explicitly presented for the City of Bogor but instead aggregated for the whole JMA domain [8]. Afterward, there have been no updates on the air pollutant EI study conducted for Bogor City till now on. This article presented the initial results of the EI for Bogor City for the 2016 base year, which was based on the activity data compiled in the 2016 Bogor City GHG EI. The results were used as the basis for the preparation of emission sourcewise CAAP for the city.

\section{METHODS}

\section{Background information of Bogor City}

Bogor City was inhabited by nearly 1.1 million people in 2016 , with the annual growth rate of $1.53 \%$ [9]. The number of registered vehicles was recorded of 1,080,000 units in the same year, and the number may increase substantially during the weekend and holiday [9]. The total sale of fuel for onroad transport in the city reached 102,000 kiloliters (KL) in 2016 (Premium), while for Pertamax, diesel, and biodiesel fuels were recorded of $35,000,4,177$, and 16,000 KL, respectively [10]. The industrial sector mainly used natural gas, in which an annual total consumption was reported at $353 \times 10^{6}$ 
$\mathrm{m}^{3}$. Domestic cooking in the households mainly consumed Liquefied Petroleum Gas (LPG), and the reported annual consumption in 2016 was 31 kiloton [10].

\section{Identification of Air Pollutant Sources}

Identification of sources that contribute to air pollution in urban areas is the first step that must be taken before conducting EI activities. The next step is to determine the type of sources that will be in inventory. We reviewed the previous EI works to analyze the emission source and pollutant coverage [8]. An EI that was developed for Indonesian cities with similar population size and characteristics such as for Surakarta, Central Java [11] was carefully considered. The results of the GHGs EI for Bogor City in 2016 were also considered to determine the activity data and the type of source [10]. Based on the above considerations, the sources of air pollutants for Bogor City in the 2016 base year were divided into three groups, namely point, area, and mobile sources.

1) Point source: A point source was a single identifiable source of pollution, such as factory stacks and hospital incinerators. The Bogor City Environmental Agency has measured the emissions of industrial stacks; thus, we used the data for emission estimates. The emissions from the above industries were from generators and boilers that use natural gas fuel from PT Perusahaan Gas Negara (PGN Co, Ltd) and coal. In cases when there is no available stack data, the source was included in the area source category.

2) Area source: Area sources are sources that individually emit a small number of pollutants via the same type of activity and collectively contributed in a significant amount of emissions. Sources in this category in Bogor City are as follows:

- Industries that were included in the point source category.
- Household activities and commercial facilities in urban areas such as offices, restaurants, etc.

- Fugitive emissions from public fuel distribution facilities (SPBU).

- Activities in agriculture and animal husbandry sector such as open burning of straw, fertilizer use, management of livestock, and feces.

- Activities in solid waste management sector such as open burning of waste, and processing of medical waste with incinerators.

3) Mobile source: Mobile sources are generally divided into two, on-road (passenger cars, motorbikes, public transportation, taxis, buses, etc.) and nonroad mobile sources (trains, airplanes, boats, etc.). In the city of Bogor, only onroad mobile sources were included in the calculations due to the lack of non-road mobile sources. Trains operating in the city run on electricity and are therefore free of emissions.

\section{The distribution of pollutant types}

The distribution of pollutant types based on types of sources is shown in Table 1. Some air pollutants are criteria pollutants included in PPRI No. 41 the year 1999 [12] such as $\mathrm{SO}_{2}, \mathrm{CO}, \mathrm{NO}_{2}, \mathrm{PM}_{10}, \mathrm{PM}_{2.5}$, and $\mathrm{HC}$ (in total VOC). These parameters can have adverse effects on health if its presence in the air exceed the ambient air quality standard. In addition, there are additional two parameters which are not included in PPRI No. 41 year 1999 namely organic carbon (OC) and black carbon (BC). The latter contributed to about $17-45 \%$ to the total fine particulates measured in the ambient air in several Indonesian cities [13]. $\mathrm{BC}$ is a black component that is a product of incomplete combustion and can absorb sunlight radiation so that it can cause global warming. At the same time, OC contains organics that can transmit sunlight radiation, and its presence in the atmosphere can cause 
Table 1. Type of air pollutants listed by type of pollutant source

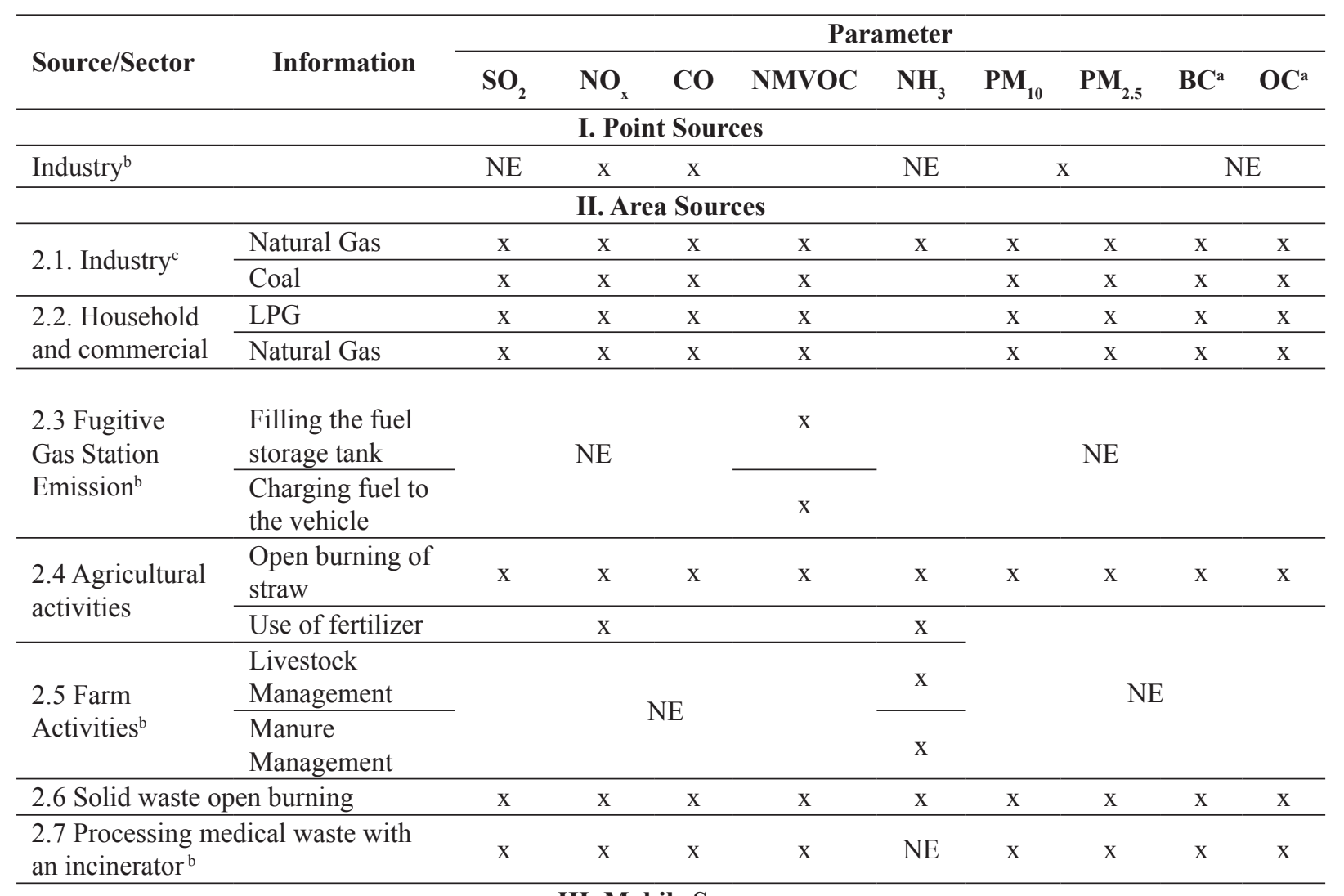

\begin{tabular}{lllllllllll}
\hline \multicolumn{11}{c}{ III. Mobile Sources } \\
\hline $\begin{array}{l}\text { Motorized } \\
\text { vehicles on the } \\
\text { highway }\end{array}$ & Gasoline & $\mathrm{x}$ & $\mathrm{x}$ & $\mathrm{x}$ & $\mathrm{x}$ & $\mathrm{NE}$ & $\mathrm{x}$ & $\mathrm{x}$ & $\mathrm{x}$ & $\mathrm{x}$ \\
\cline { 2 - 11 } & Diesel & $\mathrm{x}$ & $\mathrm{x}$ & $\mathrm{x}$ & $\mathrm{x}$ & $\mathrm{NE}$ & $\mathrm{x}$ & $\mathrm{x}$ & $\mathrm{x}$ & $\mathrm{x}$ \\
\hline
\end{tabular}

a Black carbon $(B C)$ and organic carbon $(O C)$ are components of particulates that play a role in climate change due to their optical properties in absorbing and scattering sunlight radiation (not included in PPRI No. 41 of 1999 ${ }_{12}$ ) ${ }^{b} N E$ : these sources were not estimated for some certain pollutants because the pollutants were not emitted from those particular emission sources, or in other cases, the emission factors were rarely available.

These emission factors were generated from source characterization/emission measurements, and the data are generally presented in a number of pollutants released to the atmosphere per unit of activity data (e.g., amount of fuel burned in a combustion device.

${ }^{c}$ Industry here is not included in the point source.

cooling globally [14]. Quantification of the emission load of these two pollutants is useful to explain the relationship between air pollution and global warming.

\section{Emission Estimation}

Various EI methodologies have been described in various international sources [15-18]. For Indonesia, the methods for EI has been summarized in the Technical Guidelines for Preparing Air Pollutant Emissions Inventories in Cities $\left(\mathrm{KLHK}_{5}\right)$. Due to limited resources and time, the IE study for Bogor City used a "top-down" approach, and many used "tier 1" using the fuel consumption approach, except for the calculation of point source emissions and emissions from gas stations. A disadvantage of using this method is that it does not explicitly include the efficiency level of air pollution control. Data from Bogor City 2016 GHGs EI was also adopted for consistency in GHG calculations and air pollutants [10]. In the final IE results, GHG calculations were likewise attached to the effects of EI air pollutants. Data sources and calculation methodologies are presented in Table 2 below. 
Table 2. Data Sources and calculation methodology used

\begin{tabular}{|c|c|c|}
\hline Source/Sector & Acitivity Data & Calculation Method $^{\mathrm{b}}$ \\
\hline \multicolumn{3}{|l|}{ I. Stationary Sources } \\
\hline Industry & $\begin{array}{l}\text { Emission measurement in stacks } \\
\left(\mathrm{DLHK}_{19}\right)\end{array}$ & $\operatorname{Tier} 3^{\mathrm{a}}$ \\
\hline \multicolumn{3}{|l|}{ II. Area Sources ${ }^{b}$} \\
\hline 2.1. Industry & Fuel Consumption & Tier 1 \\
\hline $\begin{array}{l}\text { 2.2. Household and commercial } \\
\text { establishments }\end{array}$ & Fuel Consumption & Tier 1 \\
\hline 2.3 Fugitive Gas Station Emission & $\begin{array}{l}\text { Gasoline sold (for premium and } \\
\text { pertamax) }\end{array}$ & $\operatorname{Tier} 2^{c}$ \\
\hline 2.4 Agricultural activities & Amount of straw burned & Tier 1 \\
\hline 2.5 Farming activities & Number of livestock & Tier 1 \\
\hline 2.6 Open burning of garbage & $\begin{array}{l}\text { Number of open burning waste } \\
\text { (not collected on landfills) }\end{array}$ & Tier 1 \\
\hline $\begin{array}{l}\text { 2.7 Processing medical waste with } \\
\text { an incinerator }\end{array}$ & $\begin{array}{l}\text { Amount of medical waste } \\
\text { treated with incinerator }\end{array}$ & Tier 1 \\
\hline \multicolumn{3}{|l|}{ III. Mobile Sources ${ }^{b}$} \\
\hline On-road motor vehicles & Amount and type of fuel sold & Tier 1 \\
\hline \multicolumn{3}{|c|}{$\begin{array}{l}{ }_{a} E m=Q g a s \times C, \text { the flow rate was obtained from the results of stack emission measurements from the Bogor City } \\
D L H . \\
{ }_{b} E m=E F \times A R\end{array}$} \\
\hline
\end{tabular}

\section{Emission factors}

Emission Factors were defined as the number of pollutants emitted from burning a certain amount of fuel (for the combustion process) or per unit of activity data for sources, not from combustion, are needed when doing EI. This EI compilation uses an Excel Sheet from the Atmospheric Brown Cloud Emission Inventory Manual (ABC EIM) [18]. The emission factors used in ABC EIM were from international sources for high-efficiency combustion [15][16][20] and emission factors from typical sources in developing countries such as burning straw and burning waste. Details of the use of emission factors in this study are the same as the emissions inventory for Indonesia [6]. Note that because the activity data collected from the existing GHG inventory did not provide information related to the emission control measures, thus "uncontrolled" and "controlled" EFs were applied based on the ABC EIM database.

\section{RESULTS AND DISCUSSION}

\section{Total emission and emission source contributions}

The results of the calculation of total air pollutant emissions are shown in Table 3, along with the results of the Bogor City GHG inventory in 2016. The total emissions for $\mathrm{SO}_{2}, \mathrm{NO}_{\mathrm{x}}, \mathrm{CO}, \mathrm{VOC}, \mathrm{NH}_{3}, \mathrm{PM}_{10}$ and $\mathrm{PM}_{2.5}$ are (in kiloton/year): $0.35,18,685,12,0.7$, 0.77 and 0.76 . The contribution of the main pollutant sources to total emissions is shown in Figure 1. Transportation contributes as much as $60 \%$ to the total $\mathrm{SO}_{2}$ emissions in Bogor City while the industry contributes $36 \%$, followed by the household sector. 
Table 3. Total air pollution and GHG emissions (Tons/year)

\begin{tabular}{|c|c|c|c|c|c|c|c|c|c|c|c|c|c|}
\hline \multirow[t]{2}{*}{$\begin{array}{l}\text { Source/ } \\
\text { Sector }\end{array}$} & \multirow[t]{2}{*}{ Subsector } & \multicolumn{9}{|c|}{ Air pollutant emissions (Ton/year) ${ }^{\mathrm{a}}$} & \multicolumn{3}{|c|}{$\begin{array}{l}\text { GHG Emissions } \\
\text { (Ton/year) }^{\mathrm{b}}\end{array}$} \\
\hline & & $\mathrm{SO}_{2}$ & $\mathrm{NO}_{\mathrm{x}}$ & $\mathrm{CO}$ & VOC & $\mathrm{NH}_{3}$ & $\mathbf{P M}_{10}$ & $\mathbf{P M}_{2.5}$ & BC & OC & $\mathrm{CH}_{4}$ & $\mathrm{CO}_{2}$ & $\mathrm{~N}_{2} \mathrm{O}$ \\
\hline \multicolumn{14}{|l|}{ I. Point Sources } \\
\hline \multicolumn{2}{|c|}{ Industry (8 industries) } & 17 & 20 & 1,952 & NE & $\mathrm{NE}$ & 16.27 & 14.65 & NE & $\mathrm{NE}$ & $\mathrm{NE}$ & $\mathrm{NE}$ & $\mathrm{NE}$ \\
\hline \multicolumn{14}{|l|}{ II. Area Sources } \\
\hline \multirow[t]{2}{*}{ 2.1. Industry } & Natural gas & 101 & 16,633 & 626,140 & 1,573 & 412 & 6.92 & 7.49 & 0.63 & 6.29 & 67 & 742,843 & 1.38 \\
\hline & Charcoal & 0.0045 & 0.01 & 0.40 & 0.005 & 0 & 0.015 & 0.012 & 0.0010 & 0.0025 & 3.22 & 19 & 0.0004 \\
\hline \multirow{2}{*}{$\begin{array}{l}\text { 2.2. Household } \\
\text { and commer- } \\
\text { cial establish- } \\
\text { ments }\end{array}$} & LPG & 10 & 55 & 116 & 7.33 & $\mathrm{NE}$ & 8.11 & 8.11 & 1.56 & 0.94 & 0.09 & 93,542 & 0.09 \\
\hline & Natural gas & 3.71 & 8.77 & 7.31 & 0.70 & $\mathrm{NE}$ & 0.0015 & 0.0015 & 0.0001 & 0.000037 & 0.87 & 9,569 & 0.02 \\
\hline \multirow[t]{2}{*}{$\begin{array}{l}2.3 \text { Fugitive } \\
\text { emissions }\end{array}$} & $\begin{array}{l}\text { Filling of } \\
\text { storage tank }\end{array}$ & $\mathrm{NE}$ & $\mathrm{NE}$ & $\mathrm{NE}$ & 208 & $\mathrm{NE}$ & $\mathrm{NE}$ & $\mathrm{NE}$ & $\mathrm{NE}$ & $\mathrm{NE}$ & $\mathrm{NE}$ & $\mathrm{NE}$ & $\mathrm{NE}$ \\
\hline & $\begin{array}{l}\text { Filling of } \\
\text { vehicles }\end{array}$ & $\mathrm{NE}$ & NE & NE & 193 & $\mathrm{NE}$ & $\mathrm{NE}$ & $\mathrm{NE}$ & $\mathrm{NE}$ & $\mathrm{NE}$ & NE & $\mathrm{NE}$ & $\mathrm{NE}$ \\
\hline \multirow{2}{*}{$\begin{array}{l}2.4 \\
\text { Agricultu- } \\
\text { ral activities }\end{array}$} & $\begin{array}{l}\text { Open burning } \\
\text { of straw }\end{array}$ & 0.58 & 7.30 & 573 & 22 & 13.12 & 29 & 27 & 1.63 & 9.28 & 8.60 & 1.50 & 0.22 \\
\hline & Fertilizer use & $\mathrm{NE}$ & 8.20 & $\mathrm{NE}$ & $\mathrm{NE}$ & 78 & $\mathrm{NE}$ & $\mathrm{NE}$ & $\mathrm{NE}$ & $\mathrm{NE}$ & 8.73 & 1.60 & 38 \\
\hline \multirow[t]{2}{*}{$\begin{array}{l}2.5 \text { Farming } \\
\text { activities }\end{array}$} & $\begin{array}{l}\text { Livestock } \\
\text { manage- } \\
\text { ment }\end{array}$ & $\mathrm{NE}$ & $\mathrm{NE}$ & $\mathrm{NE}$ & $\mathrm{NE}$ & 233 & $\mathrm{NE}$ & $\mathrm{NE}$ & $\mathrm{NE}$ & $\mathrm{NE}$ & 39 & $\mathrm{NE}$ & 0.00 \\
\hline & $\begin{array}{l}\text { Manure } \\
\text { manage- } \\
\text { ment }\end{array}$ & $\mathrm{NE}$ & $\mathrm{NE}$ & $\mathrm{NE}$ & NE & $\mathrm{NE}$ & $\mathrm{NE}$ & $\mathrm{NE}$ & $\mathrm{NE}$ & $\mathrm{NE}$ & 141 & $\mathrm{NE}$ & 335 \\
\hline \multicolumn{2}{|c|}{$\begin{array}{l}2.6 \\
\text { Open burning of garbage }\end{array}$} & 1.08 & 6.50 & 91 & 32.48 & 2.04 & 21 & 17 & 12 & 12 & 8.16 & 460.00 & 0.19 \\
\hline \multicolumn{2}{|c|}{$\begin{array}{l}2.7 \\
\text { Processing medical waste with an } \\
\text { incinerator }\end{array}$} & 0.08 & 3.25 & 0.14 & 8.01 & $\mathrm{NE}$ & 45 & 45 & 1.59 & 0.26 & 7.00 & 2,500 & 0.16 \\
\hline \multicolumn{14}{|c|}{ III. Mobile Sources } \\
\hline \multirow{2}{*}{$\begin{array}{l}\text { On-road } \\
\text { motorized } \\
\text { vehicles }\end{array}$} & Gasoline & 97 & 1,259 & 54,412 & 9,772 & $\mathrm{NE}$ & 576 & 576 & 1.28 & 5.91 & 0.14 & 315,072 & 0.02 \\
\hline & Diesel & 110 & 326 & 341 & 84 & $\mathrm{NE}$ & 78 & 78 & 23 & 17 & $\begin{array}{l}0.0 \\
03\end{array}$ & $\begin{array}{l}52 \\
522\end{array}$ & $\begin{array}{l}0.0 \\
03\end{array}$ \\
\hline \multicolumn{2}{|c|}{ GRAND TOTAL } & 349 & 18,345 & 684,644 & 11,901 & 738 & 770 & 764 & 42 & 51 & 283 & $\begin{array}{c}1, \\
216,530\end{array}$ & 375 \\
\hline
\end{tabular}

Although the sulfur content in pertamax fuel has been reduced to $50 \mathrm{ppm}$ following the specifications prepared by PT Pertamina, the sulfur contents in Premium and Diesel Oil was still high (above 1,000 ppm) [21]. The sulfur content in natural gas was quite small of nearly $200 \mathrm{ppm}$, although it has been used as the main fuel in the industry sector, and with a consumption reached 16,000 tons/ year [22]. The majority of $\mathrm{NO}_{\mathrm{x}}$ emissions came from burning of natural gas in the industrial sector $(91 \%)$, with the rest coming from the transportation sector.

$\mathrm{NO}_{x}$ emissions came from combustion with very high temperatures, which can occur either in industrial-owned boilers or generators. Total $\mathrm{NO}_{\mathrm{x}}$ emissions from motorized vehicles were lower due to lower overall fuel consumption and lower temperatures and the use of catalysts that can reduce $\mathrm{NO}_{x}$ emissions [20]. The same pattern was observed with $\mathrm{CO}$ emissions. Although the level of combustion efficiency in the industry was higher than motorized vehicles, fuel consumption was much higher. Nonmethane volatile organic carbon (NMVOC) emission from motorized vehicles (in the form of $\mathrm{HC}$ ) is higher ( $83 \%$ ) compared to emissions from the industry sector $(13 \%)$ because of the evaporation of VOCs when idling and during ignition of motor vehicles (hot start and cold start).

The contribution of VOC evaporation from gas stations was also quite significant (4\%), and these emissions occur when filling the station tank and the vehicles, with emissions from gasoline being particularly high. The transportation sector was the 

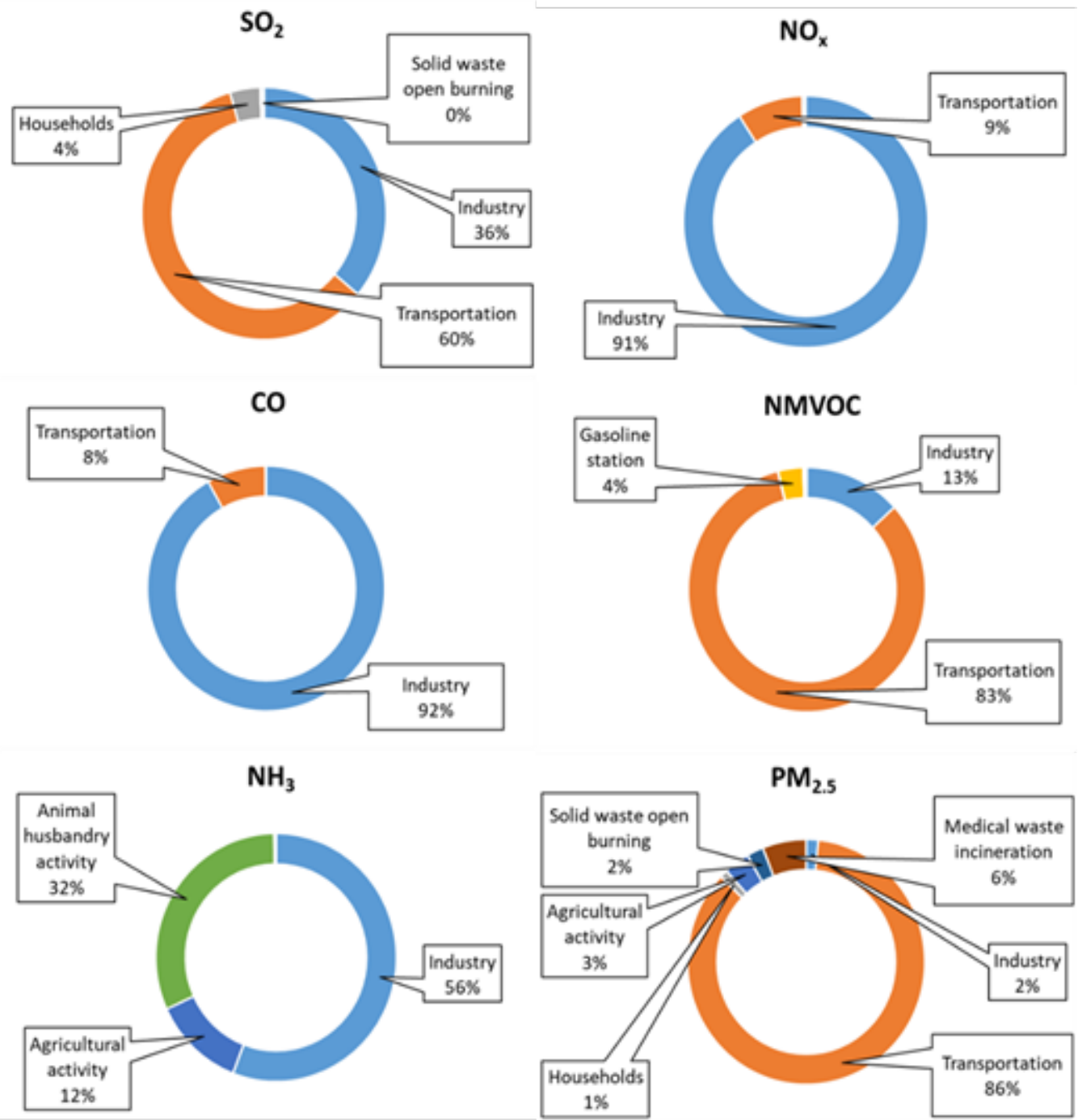

Figure 1. Contribution of pollutant sources to total emissions for each type of pollutant.

dominant source of $\mathrm{PM}_{2.5}$ due to the use of fossil fuel. Other sources were medical waste incinerators in hospitals $(6 \%)$ and open burning of garbage and straw after harvest $(5 \%)$. The industry only contributed $2 \%$ due to minimizing emissions from the burning of natural gas. Ammonia was widely emitted by industry because of the high nitrogen content in natural gas followed by activities in agriculture and livestock, especially fertilizer use and livestock management.

We compared the results with those compiled for the City of Bandung in 2002 [23], and we obtained some discrepancies which depend on the emission sources available in the cities. For $\mathrm{CO}$ and $\mathrm{NO}_{x}$, on-road transport in Bandung contributed far higher than that we found in Bogor, for i.e. $93 \%$ and $53 \%$, respectively. This was due to more intensive industrial activity, which resulted in higher fuel consumption (natural gas) in Bogor. On-road transport contributed $68 \%$ to the total emission of NMVOC in Bandung, while in Bogor, its share was higher of $83 \%$. For particulates, the shares of on-road transport in Bogor was higher $(86 \%)$ than that reported for Bandung of $28 \%$. Overall, the magnitude of emission estimates was logical, considering the size and source intensity of both cities. 
Note that the EI conducted for Bogor used fuel consumption data, while in Bandung, more bottom-up method (through a survey) was done; therefore, we expected these discrepancies.

\section{a. Considerations for emission source- wise CAAP}

From the results of the emissions inventory above, the following are some important notes in the preparation of the source-wise CAAP:

1) Both air pollutants and GHGs, for fuelburning sources, will be released into ambient air (co-emitted). Therefore, actions are needed to be taken that could potentially reduce both air pollutants and GHGs;

2) The most significant contributor to each type of pollutant is different. Therefore, the type of action for a particular sector will be determined by the type of pollutant being reduced (see Table 4);

3) In Bogor City, the transportation sector is the dominant contributor to $\mathrm{SO}_{2}, \mathrm{VOC}$, and $\mathrm{PM}_{2.5}$ pollutants while the industry is the dominant contributor for NOx and CO pollutants (see Table 4);

4) In addition to the primary pollutants above (pollutants directly emitted from the source), the formation of secondary pollutants (ozone, secondary PM) should also be taken into account.
Information presented in Table 4 can be used to prioritize emission reduction measures to be specified in the CAAP document. Also, measures should be carefully considered to reduce both air pollutants and GHGs at the same time to achieve clean air - climate co-benefits. For example, emission reduction measures for fuel combustion in the industrial sector should aim for $\mathrm{NO}_{x}, \mathrm{CO}, \mathrm{CO}_{2}, \mathrm{CH}_{4}$ simultaneously by introducing green energy, fuel safety and installment of air pollution control devices for the point sources. National program on fuel quality improvement, stringent engine standards (EURO IV), better mass rapid traffic management, and introduction of the non-motorized vehicle could help to cut down the emissions of $\mathrm{SO}_{2}, \mathrm{NMVOC}, \mathrm{PM}$ and $\mathrm{CO}_{2}$ significantly.

\section{CONCLUSION}

The development of City CAAP requires sufficient baseline data on air quality management, and one of the important technical tools is EI. Emission inventory provides an estimation of emission relative strength and can provide source apportionment information. The results can be used as a basis to prioritize the emission reduction strategy in the CAAP. Top-down EI was used in this study for Bogor City to preliminary estimate the total emissions of air

Table 4. Top contributors to air pollutants and greenhouse gas emissions in Bogor City

\begin{tabular}{cl}
\hline Parameter & \multicolumn{1}{c}{ Contributor/Source of Emission * } \\
\hline $\mathrm{NO}_{x}$ & Industry, transportation, household, burning of straw and burning of waste \\
\hline $\mathrm{SO}_{2}$ & Transportation, industry, household, garbage burning, straw burning \\
\hline $\mathrm{CO}$ & Industry, transportation, burning of straw, household, burning of waste \\
\hline $\mathrm{NMVOC}$ & Transportation, industry, gas stations, burning open waste, burning straw \\
\hline $\mathrm{PM}_{10} / \mathrm{PM}_{2.5}$ & $\begin{array}{l}\text { Transportation, incineration of medical waste, burning of straw, burning of } \\
\text { waste }\end{array}$ \\
\hline $\mathrm{CO}_{2}$ & Industry, transportation, household, incineration of medical waste \\
\hline $\mathrm{CH}_{4}$ & Industry, livestock activities, burning of straw, open burning of waste \\
\hline $\mathrm{N}_{2} \mathrm{O}$ & Livestock activities, agricultural activities, industry, open waste burning \\
\hline
\end{tabular}

* Ranked from the most significant contribution seen on the EI results. 
pollutants. Transportation contributed $60 \%$ of total $\mathrm{SO}_{2}$ emission followed by industry $(36 \%)$ and others (collectively shared only $4 \%$ ). It also dominantly contributed to the total emissions of NMVOC $(83 \%)$ and $\mathrm{PM}_{2.5}$ $(86 \%)$. The industry contributed dominantly to the total emissions of $\mathrm{NO}_{\mathrm{x}}(91 \%), \mathrm{CO}$ (92\%), and $\mathrm{NH}_{3}(56 \%)$. Those are major contributors to the total airpollutantemissions in Bogor City. Hence prioritization should be done to address those sources. Before CAAP development, both air pollutants and GHGs emission data should be analyzed; hence measures can consider the efficacy of both emission reductions. Then, emission reduction measures can be formulated based on the major contributing sources.

\section{ACKNOWLEDGMENT}

The Authors acknowledge the Bogor City government, including City Planning Agency (BAPPEDA Kota) and City Environmental Agency (DLHK), for providing valuable data for the EI compilation. Clean Air Asia is highly acknowledged for the funding support under the Integrated Programme on Better Air Quality (IBAQ) Project.

\section{REFERENCES}

1. Widowati, Haryanto B. Hubungan antara tingkat konsentrasi $\mathrm{NO}_{2}, \mathrm{SO}_{2}$ dan $\mathrm{PM}_{10}$ di udara ambient dengan kejadian ISPA penduduk kecamatan Taman Sari Jakarta Barat 2006-2013. 2014. Program kesehatan Masyarakat, Fakultas Kesehatan Masyarakat Universitas Indonesia, Master Thesis;

2. Vichit-Vadakan N, Vajanapoom N, Ostro B. The Public Health and Air Pollution in Asia (PAPA) Project: Estimating the Mortality Effects of Particulate Matter in Bangkok, Thailand. Environ Health Perspect. 2008. 116(9), 1179-1182;

3. Clean Air Asia. Clean Air Action Planning and the Role of the Health Sector. 2019. Clean Air Asia, article accessed on 14 April 2020 from https://events.development.asia/ system/files/materials/2019/10/201910- clean-air-action-planning-and-role-healthsector-english.pdf;

4. Vu TV, Shi Z, Cheng J, Zhang Q, He K, Wang S, Harrison RM. Assessing the impact of clean air action on air quality trends in Beijing using a machine learning technique, Atmos. Chem. Phys., 19, 11303-11314, https://doi.org/10.5194/acp-19-11303-2019, 2019.

5. KLHK. Pedoman teknis penyusunan inventarisasi emisi pencemar udara di perkotaan. 2013. Proyek Clean Air for Smaller Cities GiZ: Jakarta, Indonesia.

6. Permadi DA, Sofyan A, Kim Oanh NT. Assessment of emissions of greenhouse gases and air pollutants in Indonesia and impacts of national policy for elimination of kerosene use in cooking. Atmospheric Environment. 2018. 154, 82-94.

7. Soedomo M. Pencemaran Udara. ITB Press. 2001, Bandung.

8. JICA. The study on the integrated air quality management for Jakarta metropolitan area final report. 1997. Japan International Cooperation Agency : Nippon Koei Co., Ltd. : Suuri Keikaku Co., Ltd.

9. BPS. Kota Bogor dalam angka 2017. 2017. Badan Pusat Statistik Kota Bogor.

10. Bappeda. Laporan akhir inventarisasi dan identifikasi penghitungan emisi gas rumah kaca. 2017. Laporan disampaikan ke Bappeda oleh PT Ahassa Ciptanika, Bogor, Indonesia.

11. Sutrisno AM, Huboyo HS, Sutrisno E. Kajian prediksi beban emisi pencemar udara (TSP, $\mathrm{NO}_{\mathrm{x}}, \mathrm{SO}_{2}, \mathrm{HC}$, dan $\mathrm{CO}$ ) dan gas rumah kaca $\left(\mathrm{CO}_{2}, \mathrm{CH}_{4}\right.$, dan $\left.\mathrm{N}_{2} \mathrm{O}\right)$ sektor transportasi darat di Kota Surakarta dengan metode top down dan bottom up. 2016. Jurnal Teknik Lingkungan. 5(1).

12. Peraturan Pemerintah No 41 tahun 1999 tentang Pengendalian Pencemaran Udara

13. Santoso M, Dwiana D, Hopke PK. Atmospheric black carbon in $\mathrm{PM}_{2.5}$ in Indonesian cities. Journal of Air and Waste Management Association. 2013. 63(9), 1022-1025.

14. Bond TC, Streets DG, Yarber KF, Nelson SM, Woo JH, Klimont Z. A technology- 
based global inventory of black and organic carbon emissions from combustion. Journal of Geophysical Research. 2014. 109, D14203, doi:10.1029/2003JD003697.

15. IPCC. Intergovernmental Panel on Climate Change Guidelines for National Greenhouse Gas Inventories. 2016. Retrieved from http:// www.ipcc-nggip.iges.or.jp/public/2006gl/ index.html.

16. EMEP/EEA. European Monitoring and Evaluation Programme/European Environment Agency (EMEP/EEA) air pollutant emission inventory guidebook, 2016. European Environment Agency (EEA). 2016. Retrieved from http://www. eea.europa.eu/publications/.

17. GAPF. Global Air Pollution Forum Emission Manual. 2013. Retrieved from https://www. sei.org/projects-and-tools/tools/gap-globalair-pollution-forum-emission-manual/.

18. Shrestha RM, Kim Oanh NT, Shrestha R, Rupakheti M, Permadi DA, Kanabkaew T, Salony R. Atmospheric Brown Cloud (ABC) Emission Inventory Manual (EIM). United Nation Environmental Programme (UNEP). 2010: Nairobi, Kenya.

19. Dinas Lingkungan Hidup. Laporan pengujian emisi sumber bergerak Kota Bogor 2018. 2018. Laporan dari PT Sky Pacific Indonesia: Bogor, Indonesia.
20. AP-41 US EPA. Updates on the 5th editions of AP-42 Volume 1: Compilation of Air Pollutant Emission Factors, Volume 1: Stationary Point and Area Sources. 2017. Retrieved from https://www.epa.gov/airemissions-factors-and-quantification/ap-42compilation-air-emission-factors.

21. Kim Oanh NT, Huy L, Permadi DA, Zusman E, Nakano R, Nugroho S, Sofyan $\mathrm{S}$, Lestari P. Assessment of urban passenger fleet emissions to quantify climate and air quality co-benefits resulting from potential interventions. Carbon Management. 2018. 9(4), 367-381.

22. Palguna, Safrudin. Status Fuels and Vehicles Global Fuel Economy Initiative Indonesia, Partnerships for Clean Fuels and Vehicles (PCFV). 2010. Article retrieved from http://www.unep.org/Transport/PCFV/ PDF/8GPM_CleanFuelsVehiclesStatus.pdf.

23. Lestari P. Study on air quality and its impact in Bandung, West-Java, Indonesia. 2004. Paper presented at the AIRPET National Workshop, Bandung, Indonesia. 